\title{
The Impact of Students' Perception on Their Academic Background on Their Learning Motivation
}

\author{
Rendhi Fatrisna Yuniar, M.Pd \\ Universitas Islam Negeri Maulana Malik Ibrahim Malang \\ e-mail: rendhify@gmail.com
}

Keywords:

Academic performance, academic background, motivation, perception

\begin{abstract}
A B S T R A C T
Students' academic performance is influenced by many factors such as previous academic background and level of motivation. There have been several studies trying to find out the correlation between students' previous academic background and their learning achievement. However, the results are not convincing. Though it is found out that there is a correlation between students' academic background and their learning achievement, the value of the correlation is small. There have also been many researches investigating the impact of students' motivation and their academic gain. However, the correlational study on students' perception on academic background and their learning motivation is rare undertaking.
\end{abstract}

\section{INTRODUCTION}

Students' academic gain is influenced by numerous factors including gender, age, teaching faculty, students' schooling/ family economic status, medium of instruction in schools, daily study hour and their learning motivation. Motivation refers to "the reasons underlying behavior" (Guay et all, 2010). Another definition of motivation is given by Broussard and Garrison (2004) who define that motivation is the attribute that moves us to do or not to do something. There are two types of motivation; namely intrinsic and extrinsic motivation. According to Dornyei (2001), motivation concern brings sequel on how hard learners act to achieve their goal and why students settle their plan to achieve the goal. Motivation is one of the most important aspects on learning since it is a kind of desire in learning (Anjomshoa and Sadighi, 2015). Motivation is one of the factors that take a big role on students' success in teaching and learning process. Deci et all (1999) summarizes that spontaneous satisfactions inherent in effective discretion action is sustained by intrinsic motivation. Researchers often contrast intrinsic motivation with extrinsic motivation which is governed by reinforcement contingencies.

Motivation is one of the factors that contribute to students' achievements on writing. Motivation is one of the most important aspects on learning since it is a kind of desire in learning (Anjomshoa and Sadighi, 2015). The limited strategies use in English writing class which are not accordance with the times is one of the factors that demotivate students to write in English. Due to the fact that writing is the most complex skill rather than the other skills, the emphasizing of giving appropriate motivation needs to be done. Without appropriate motivation, the goal of teaching and learning process cannot be achieved (Harmer, 2007). Since motivation plays important roles on students' achievement, especially in writing, the researcher relates students' perception on their academic background on students' motivation. It is supported by a theory from Harmer (2007) who describes motivation as a key to forces students to do the task and emphasizes that motivation can be influenced by the strategy used by the teacher. 
There is a reason to believe that students' previous schooling influenced their motivation and achievement. It is generally assumed that students who show better or higher performance in their starting classes of their studies will have higher motivation and perform better in future academic years at upper level. This theory is supported by a research conducted by Hanushek \& Rivkin (2010) which stated that students' academic background contributes to students' performance. Durden and Ellis (in Staffolani and Bratti, 2002) also found that the most important indicator of students' future achievement is the student's previous educational outcomes. Previous studies have found that teachers vary considerably in their ability to identify student's future performance based on students' academic background (Backes \& Hansen, 2015; Gershenson, 2016). It means that the higher the previous performance, the better students' performance in future endeavors will be. However, it is found out that many researchers do not agree with that point of view. Reddy and Talcott (2006) disagreed with the assumption that future academic gains and motivation will be reflected from previous academic performance. Their research revealed that the students learning at graduate level and their sore did not predict any academic achievement at University levels. It is also confirmed in the study of Oregon State University on graduate admissions that normal measures of educational potential and academic performance such as High School GPA showed only 30\% of the deviation in initial or starting (first year) at college. They confirmed that the admission scores are related to academic performance at university level, but to a very minimal extend. Mc Donald et all (2001) also stated that the scores of graduate level studies are still out performed any other single measure of cognitive aptitude in predicting success at university level. Thus, it can be concluded that students' academic background gives a small prediction on students' academic performance at higher level of education.

As stated above, students' academic performance and gain are influenced by students' motivation. There have been researched on correlation between students' academic background and their future academic performance at higher education level. According to Bandura (2012) and Schunk et all (2002), students' motivation brings an effect on students' academic performance. However, the previous study conducted in which the researchers aimed to figure out students' educational background and their future achievement is conducted in previous decades. One of them is a study conducted by Bandura (1997) which emphasized on self- efficacy (SE) becomes the major point and refers to an individual's judgment of their capabilities to organize and execute courses of action required to achieve desired performances. The study shows how significantly importance of having high motivation in order to enhance students' academic performance. The other study is "Academic Achievement and Future Time Perspective as a Cognitive-Motivational Concept by Volder (1982)". The result of the aforementioned study shows that there is no correlation between students' educational background and students' achievement in the future since there are several special issues come up in that study. In other words, it cannot be generalized when several special issues come up in a study. Therefore, this study is needed to be conducted. Moreover, research on correlation between students' academic background and their learning motivation is rare undertaking.

English Teaching Department of Graduate Program at State University of Malang, in which the study was conducted, is one of the best English Education of Graduate Level in Indonesia. It is proven by the big number of undergraduate students applying to study there. To be accepted, they have to take an entrance test in a form of a written English proficiency 
test. Candidates of English Teaching Department of Graduate Program at State University of Malang have different academic background. Some of them are graduated from an English Teaching department that is relevant to their graduate program. However, some of them are graduated from somewhat irrelevant department, such as English linguistics and English Letters Department. It is found out that those who are accepted at the English Teaching Department of Graduate Program at State University of Malang are those who graduated from not only English Teaching Department, but also English Linguistics and English Letters. It is assumed that students who graduated from English teaching department will be easier to study than those who graduated from other department and therefore they have higher learning motivation.

This study aims at exploring the impact of students' perception on their academic background on their learning motivation in Graduate Program at State University of Malang. This research tries to prove whether students graduated from English Teaching Department Have Higher Learning Motivation than those Graduated not from English Teaching Department.

\section{METHOD}

The method use in this study will be elaborated in this section. This section covers three areas namely participants, instruments and research design. Each area will be described below.

\subsection{Participants.}

The participants of this study are students of English Department at Graduate Program of State University of Malang from batch 2017. There are 75 students who are divided into three classes namely class A, B and C. They are accepted after passing an entrance test in English Department of Graduate Program at State University of Malang. There are 40 students out of 75 filling out the questionnaire. Table 1 gives some descriptive information about the participants.

Table 1. Participants

\begin{tabular}{ccccc}
\hline & ELT & NON-ELT & MALE & FEMALE \\
\hline $\mathrm{N}$ & 30 & 10 & 16 & 24 \\
\hline
\end{tabular}

\subsection{Instrument}

In order to collect quantitative data, a questionnaire was developed by the researcher. It is a five point-Likert scale containing 12 items and is used to find out students' perception on their academic background and their learning motivation. It is an online questionnaire using Googledocs. The researcher distributed a web address to students and asked them to fill out the questionnaire. Items no one up to no six are used to find out students' perception on their academic background and items no seven up to twelve are used to find out their learning motivation. The options range from strongly disagree (1) disagree (2) neither agree nor disagree (3) agree (4) and strongly agree (5). 


\subsection{Research Design}

In this study, a correlational research design is employed. The aim is not to find out the effect of variable with independent variable as in the experimental design, but to define the relations between two variables. The degrees of two or more quantitative variables related is described as a correlation study (Fraenkel, Wallen and Hyun, 2010)

In this study, data are gathered by using online questionnaires. The researchers disseminated a web address for online questionnaire through WhatsApp group and asked the participants to fill the questionnaire out. After the data were collected, the statistical analysis was conducted by using a statistic program named "SPSS 22.0." As Tekbiyik (2014) stated that when examining the relation level of an independent variable on other variable, Pearson Correlation Analysis should be used. Therefore, in order to find out the correlation between students' academic background and their learning motivation, Pearson Product-moment correlation coefficient analysis was conducted.

\section{RESULTS AND DISCUSSION}

According to the analyzed data, some descriptive information was gathered. There are two sets of data. The first set is data of ELT students concerning their perception on their academic background and the second set is data of non-ELT students on their perception on their academic background and their learning motivation. Table 2 below gives information about the result of descriptive statistics for ELT students

Table 2. Descriptive statistics for ELT students

\begin{tabular}{cccc}
\hline & Mean & Std. Deviation & $\mathrm{N}$ \\
\hline $\begin{array}{l}\text { ELT Academic } \\
\text { Background }\end{array}$ & 3.37 &, 964 & 30 \\
Learning Motivation & 4,10 &, 712 & 30 \\
\hline
\end{tabular}

Table 3. Descriptive statistic for non-ELT students

\begin{tabular}{cccc}
\hline & Mean & $\begin{array}{c}\text { Std. } \\
\text { Deviation }\end{array}$ & $\mathrm{N}$ \\
\hline $\begin{array}{c}\text { Non-ELT Academic } \\
\text { Background }\end{array}$ & 2,80 & 1,229 & 10 \\
Learning Motivation & 3,60 &, 516 & 10
\end{tabular}

From Table 2 and 3, the data on means and standard deviation for Perception of Non-ELT Academic Background and their learning motivation and perception of ELT students on their academic background and their learning motivation are presented.

The result of correlational analysis is given in the following tables 
Table 4. Result of correlation for ELT students

\begin{tabular}{clcc}
\hline & Pearson Correlation & $\begin{array}{c}\text { ELT Academic } \\
\text { Background }\end{array}$ & $\begin{array}{c}\text { Learning } \\
\text { Motivation }\end{array}$ \\
\hline $\begin{array}{c}\text { ELT Academic } \\
\text { Background }\end{array}$ & Sig. (2-tailed) & 1 &, 296 \\
N & Pearson Correlation & 30 &, 112 \\
Learning & Sig. (2-tailed) &, 296 & 30 \\
Motivation & $\mathrm{N}$ &, 112 & 1 \\
& & 30 & 30 \\
\hline
\end{tabular}

Table 4 indicates that there is statistically positive significant correlation in the level of 0,296 between Perception of ELT students on their Academic Background and their learning motivation. It can be said that the better their perception, the higher their learning motivation.

Table 5. Result of correlation for non-ELT students

\begin{tabular}{cccc}
\hline & & $\begin{array}{c}\text { ELT Academic } \\
\text { Background }\end{array}$ & $\begin{array}{c}\text { Learning } \\
\text { Motivation }\end{array}$ \\
\hline No- ELT Academic & Pearson & 1 &,- 490 \\
Background & Correlation &, 150 \\
Sig. (2-tailed) & $\mathrm{N}$ & 10 & 10 \\
Learning Motivation & Pearson &,- 490 & 1 \\
& Correlation &, 150 & 10 \\
\hline
\end{tabular}

Table 5 shows that there is statistically negative correlation between perception of non-ELT students on their academic background and their learning motivation at the level of $-0,490$. It can be interpreted that the better the non-ELT students' perception on their academic background, the lower their learning motivation.

This study aims at exploring the impact of students' perception on their academic background on their learning motivation in Graduate Program at State University of Malang. It can be concluded that there are two groups of students involved in this study that consist of graduated students from ELT department and the other is students graduated from non-ELT department.

Based on the analysis, for ELT students, there is a positive correlation between their perception on their academic background and their learning motivation. If their perception on their academic background is good, then their learning motivation is high. It could be known from the mean and standard deviation for ELT students are more than the mean and standard deviation for non-ELT students. These results enriched the information from the previous studies on correlation between students' academic background and their future academic performance at higher education level conducted by Bandura (2012), Schunk et all (2002), and Hanushek \& Rivkin (2010) by investigating the area that has not 
been covered. This study revealed that the higher ELT student's perception on their academic background, the higher motivation that they have.

For non-ELT students, the finding shows that the correlation between their perception on academic performance and their learning motivation is negatively correlated. It means that although their perception on their academic background is good, their learning motivation is low or vice versa. It is in line with Reddy and Talcott (2006) who disagreed with the assumption that future academic gains and motivation will be reflected from previous academic performance. However, some factors such as students' non-ELT previous academic performance and students' academic knowledge related to the current material should be considered. Students' previous academic knowledge affects their motivation. Students' previous academic knowledge determines the difficulty facing by the students in teaching and learning process. Some of non- ELT students needed to make more effort in teaching and learning process.

\section{CONCLUSION}

From the discussion, it can be concluded that for students graduated from ELT, their perceptions of their academic background influence their learning motivation at English Language Department of Graduate Program at State University of Malang. The better students' perception, the higher students' learning motivation. On the other hand, for non-ELT students, their perception on their academic background doesn't influence their learning motivation. Their high learning motivation is not always due to their positive perception on their academic background.

This study provides theoretical and practical contribution in English learning and teaching area. In the term of practical contribution, this study is aimed to raise lecturer awareness about the importance of students' motivation in teaching and learning process. The information about the influence of students' ELT and non-ELT perceptions on academic background toward their learning motivation becomes evidences that theoretical contribution is brought by this study. This study also becomes reference about the correlation between students' ELT and non-ELT perceptions of their academic background according to their learning motivation. For future researchers, by observing the result of this study, they are expected to modify the method to give more precise result. Adding more variables also be expected to be done by future researcher. Future researchers can also use the result of the study as reference for further studies about academic background and students' achievement.

\section{REFERENCES}

Anjomshoa, L. and Sadighi, F. (2015). The importance of motivation in second language acquisition. International Journal on Studies in English Language and Literature, 3(2), 126-137.

Backes B, Hansen M. (2015). Teach for America impact estimates on non-tested student outcomes. National Center for Analysis of Longitudinal in Education Research. Washington, D C.

Bandura, A. (1997). Self-Efficacy: The exercise of control. New York, NY: W. H. Freeman and Company. 
Bandura, A. (2012). Social cognitive theory. In P. M. Van Lange, A. W. Kruglanski, E. Higgins (Ed.), Handbook of theories of social psychology (Vol 1) (pp. 349373). Thousand Oaks, CA: Sage Publications Ltd.

Broussard, S. C., \& Garrison, M. E. B. (2004). The relationship between classroom motivation and academic achievement in elementary school-aged children. Family and Consumer Sciences Research Journal, 33(2), 106-120.

Deci, E. L., Koestner, R., \& Ryan, R. M. (1999). A meta-analytic review of experiments examining the effects of extrinsic rewards on intrinsic motivation. Psychological Bulletin, 125(6), 627-668

Dornyei. Z. (2001). Teaching and researching motivation. London: Pearson education limited Durden, G. C. and Ellis, L. V. (1995). The effect of attendance on student learning in principles of economics. American Economic Review, 85, 343-346

Fraenkel, J.R., Wallen, N.E. \& Hyun, H. H. (2012). How to design \& evaluate research in education (8th ed.). London: McGraw Hill.

Gershenson S. Linking teacher quality, student attendance, and student achievement. Education Finance and Policy. 2016;11(2):125-149.

Guay, F., Chanal, J., Ratelle, C. F., Marsh, H. W., Larose, S., \& Boivin, M. (2010). Intrinsic, identified, and controlled types of motivation for school subjects in young elementary school children. British Journal of Educational Psychology, 80(4), 711-735.

Hanushek EA, Rivkin SG. Generalizations about using value-added measures of teacher quality. American Economic Review. 2010;100(2):267-271.

Harmer, J.(2007). The Practice of Language Teaching (4th Edition). Essex, UK: Pearson Education Limited.

Reddy, P. \& Talcott, J. (2006). Predicting university success in psychology: Are subject-specific skills important?. Retrieved on July 4, 2018

Schunk, D. \& Pajares, F. (2002). Self and self-belief in psychology and education: A historical perspective. In J. Aronson (Ed.), Improving academic achievement: Impact of psychological factors on education (p. 3-21). Academic Press. 10.1016/B978012064455-1/50004-X

Voider, M. L. \& De Lens, W. (1982). Academic achievement and future time perspective as a cognitive-motivational concept. Journal of Personality and Social Psychology, 42(3), 566-571. 